\title{
ENKAPSULASI GULA SEMUT AREN MENGGUNAKAN KITOSAN DAN MALTODEKSTRIN
}

\author{
[The Encapsulation of Arenga Sugar Powder Using Chitosan and Maltodextrine] \\ Satrijo Saloko1)*, Yeni Sulastri dan Abdul Kadir \\ Fakultas Teknologi Pangan dan Agroindustri Universitas Mataram \\ *Email: s saloko@unram.ac.id
}

Diterima 12 Januari 2021 / Disetujui 1 Februari 2021

\begin{abstract}
The Encapsulation process can protect the active compounds in palm sap by utilizing a coating material. Coating materials that can be used are chitosan and maltodextrin. The purpose of this research was to determine the effect of chitosan and maltodextrin concentrations on the encapsulation process on the quality of arenga sugar powder. The research design used a completely randomized design with 2 factors. The first factor was chitosan (0\%, $1 \%$, and 2\%). The second factor was the concentration of maltodextrin (50\% and 100\%). The analysis included water content, antioxidant activity, reducing sugars, total phenols, ash content, yield, color, morphology and particle size, and organoleptics (taste and aroma). The best treatments obtained were 2\% chitosan (C3) and maltodextrin $100 \%$ (M2) with 1.23\% water content; antioxidant activity of 37.26\%; reducing sugar of $6.57 \%$; total phenol of 7.45\%; ash content of 0.69\%; yield of 24.02\%; oHue of 80.04 ; particle size of $331.23 \mu \mathrm{m}$ with smooth surface morphology of irregular shapes; organoleptic aroma rather like and the typical aroma of arenga sugar powder is rather weak; organoleptic taste like and sweet.
\end{abstract}

Keywords: arenga sugar powder, chitosan, maltodextrine

\begin{abstract}
ABSTRAK
Proses enkapsulasi dapat melindungi senyawa aktif yang terdapat pada nira aren dengan memanfaatkan bahan penyalut. Bahan penyalut yang dapat digunakan adalah kitosan dan maltodekstrin. Tujuan dari peneliatian ini adalah untuk mengetahui pengaruh konsentrasi ki- tosan dan maltodekstrin pada proses enkapsulasi terhadap mutu gula semut aren. Rancangan Penelitian menggunakan Rancangan Acak Lengkap dengan 2 faktor. Faktor pertama kitosan (0\%, 1\%, dan 2\%). Faktor kedua yaitu konsentrasi maltodekstrin (50\% dan 100\%). Analisis yang dilakukan diantaranya kadar air, aktivitas antioksidan, gula reduksi, total fenol, kadar abu, rendemen, warna, morfologi dan ukuran partikel, dan organoleptik (rasa dan aroma). Perlakuan terbaik yang didapatkan adalah perlakuan kitosan 2\% (C3) dan maltodekstrin 100\% (M2) dengan kadar air 1,23\%; aktivitas antioksidan 37,26\%; gula reduksi 6,57\%; fenol total 7,45\%; kadar abu 0,69\%; rendemen 24,02\%; 0Hue 80,04; ukuran partikel 331,23 $\mu \mathrm{m}$ dengan morfologi permukaan halus ben- tuk tidak beraturan; organoleptik aroma agak suka dan aroma khas gula semut agak lemah; organoleptik rasa suka dan manis.
\end{abstract}

Kata Kunci: gula semut aren, kitosan, maltodekstrin

\section{PENDAHULUAN}

$\begin{array}{lccr}\text { Gula } & \text { semut merupakan bentuk } \\ \text { diversifikasi } & \text { produk gula merah yang } \\ \text { berbentuk } & \text { butiran kecil (granulasi) }\end{array}$
berdiameter antara $0,8-1,2 \mathrm{~mm}$. Bahan dasar untuk membuat gula semut adalah nira dari pohon kelapa atau pohon aren (enau). Kedua pohon ini termasuk jenis tumbuhan palmae maka dalam bahasa asing secara umum gula semut juga disebut sebagai $\mathrm{palm}$ sugar (Mustaufik dan Dwianti, 2007).

Berbagai jenis tanaman yang berpotensi untuk menghasilkan gula, antara lain: aren, kelapa, lontar, nipah, dan gewang (Anonim, 2010; Mashud et al., 2011). Produk bernilai ekonomis yang dihasilkan tanaman aren diantaranya adalah nira. Nira merupakan produk yang komposisi kimianya relatif peka terhadap perubahan lingkungan. Nira segar tanpa pengawet disimpan selama 8 jam akan mengalami penurunan $\mathrm{pH}$ dan kadar gula (Joseph, 2012).

Aren (Arenga pinnata Merr.) merupakan salah satu tumbuhan palma yang dapat tumbuh dengan baik di Indonesia. Tumbuhan ini merupakan tumbuhan tahunan dengan diameter batang berkisar 122,4-129 $\mathrm{cm}$ dan tinggi berkisar 14,23-13,8 m (Ferita et al., 2015), tumbuh tegak dan soliter (Pitopang et al., 2008). Tumbuhan aren memiliki banyak manfaat antara lain berperan 
dalam konservasi lahan dan air, penghasil ijuk, bahan bangunan, dan bahan makanan. Salah satu bahan makanan yang dapat dihasilkan oleh aren adalah nira (Pitopang et al., 2008).

Mikroorganisme yang paling dominan terdapat pada nira aren adalah khamir. Khamir yang terdapat dalam jumlah besar pada nira adalah Sacharomyces sp. Fermentasi merupakan proses alami yang tidak dapat dielakkan dari nira aren segar yang manis karena pada bahan tersebut tumbuh berbagai mikroorganisme seperti sel-sel khamir Saccharomyces sp dan bakteri Acetobacter aceti (Timotius, 1982). Rasa asam pada nira aren diakibatkan oleh fermentasi yang dilakukan oleh khamir genus Saccharomyces yang menghasilkan etanol, yang kemudian etanol tersebut mengalami oksidasi akibat dari bakteri Acetobacter sehingga terbentuknya asam asetat pada nira aren (Muchtadi, 2010).

Penelitian yang dilakukan oleh Badmus dkk (2016), didapatkan kandungan senyawa fenol pada gula semut sebesar 5,81\%-5,83\% sedangkan aktivitas antioksidan yang terdapat didalamnya sebesar $26,81 \%$ $28,74 \%$. Keberadaan fenol berbanding lurus dengan kandungan antioksidan yang terdapat pada suatu bahan. Untuk menjaga kandungan senyawa aktif seperti fenol yang terdapat pada nira aren maka perlu dilakukan perlakuan salah satunya adalah enkapsulasi.

Proses enkapsulasi merupakan suatu proses perlindungan bahan aktif berupa gas, cairan dan padatan menggunakan bahan penyalut atau pembungkus (Bansode et al., 2010). Penggunaan teknologi enkapsulasi terus meningkat seperti pada industri makanan dan minuman, industri farmasi, industri tekstil, dan industri kosmetik (Mishra, 2016). Jenis penyalut yang digunakan untuk proses enkapsulasi bersifat tidak beracun dan tidak bereaksi dengan bahan inti. Beberapa bahan yang sering digunakan sebagai enkapsulan yakni gum arab, whey, pati suksinat kitosan, dan maltodekstrin.

Kitosan dan maltodekstrin telah digunakan untuk proses enkapsulasi berbagai jenis senyawa bioaktif. Kitosan memberikan perlindungan yang baikterhadap inti dan dapat mengikat senyawa aktif seperti fenol, sementara maltodekstrin memiliki kelarutan yang tinggi, tidak mempunyai rasa dan aroma, serta baik untuk melindungi flavor dari oksidasi (Saloko et al., 2012). Kombinasi maltodekstrin dan kitosan sebagai enkapsulan diharapkan mampu menghasilkan enkapsulan berdimensi nano.

Kitosan merupakan hasil diasetilasi kitin, keunggulan kitosan adalah termasuk bahan alami, kitosan mempunyai muatan positif yang kuat yang dapat mengikat muatan negatif dari senyawa lain atau berperan sebagai detoksifikasi, menghambat pertumbuhan bakteri, serta mudah mengalami degradasi secara biologis dan tidak beracun (Kaho, 2006).

Maltodekstrin merupakan produk hidrolisis pati yang mengandung unit a-Dglukosa yang sebagian besar terikat melalui ikatan 1,4 glikosidik dengan DE kurang dari 20. Maltodekstrin merupakan campuran dari glukosa, maltosa, oligosakarida dan dekstrin. Maltodekstrin biasanya dideskripsikan oleh DE (Dextrose Equivalent). Maltodekstrin dengan DE yang rendah bersifat non-higroskopis, sedangkan maltodekstrin dengan $\mathrm{DE}$ tinggi cenderung menyerap air (Srihari dkk, 2010). Oleh karena itu dilakukan penelitian mengenai pengaruh konsen- trasi kitosan dan maltodekstrin pada proses enkapsulasi terhadap mutu gula semut.

\section{BAHAN DAN METODE}

\section{Bahan}

Bahan- bahan yang digunakan untuk pembuatan gula semut adalah nira aren yang diperoleh di kebun aren Kekait, kitosan yang dibeli secara online di toko Monodon, maltodekstrin (DE 15) yang dibeli secara online di FoodChem. Adapun bahan-bahan analisis sebagai berikut metanol, reagen $\mathrm{DPPH}$, etanol, reagen $\mathrm{Cu}$ katalis, aquades, air, $\mathrm{NaOH}, \mathrm{Na}_{2} \mathrm{CO}_{3}$, Folin Ciocalteu.

\section{Alat}

Alat-alat yang digunakan dalam pembuatan gula semut yakni baskom, sendok, timbangan, homogenizer, cabinet dryer merek memmort, dan loyang (ukuran $25 \mathrm{~cm} \times 30$ 
$\mathrm{cm})$. Alat-alat yang digunakan dalam proses analisis yakni oven merek memmert, cawan porselin, mortar, stirer, desikator, labu ukur $250 \mathrm{ml}$, termometer, indikator pp, pipet, erlenmeyer $250 \mathrm{ml}$, stopwatch, pemanas listrik, pH meter, label, piring atau wadah, beaker glass, alumunium foil, mikroskop merek Olympus, spektrofotometer.

\section{Metode}

Metode yang digunakan pada penelitian ini adalah metode eksperimental dengan percobaaan Laboratorium.

\section{Pelaksanaan Penelitian}

Adapun langkah-langkah dalam proses pembuatan berdasarkan Dachlan 1984 yakni sebagai berikut:

\section{a. Persiapan Bahan Baku}

Nira yang digunakan adalah nira segar yang disadap pada jam 5 pagi di kebun nira Desa Kekait, Gunung Sari.

b. Pengukuran $\mathrm{pH}$

Pada penelitian ini kadar $\mathrm{pH}$ nira diukur terlebih dahulu untuk mengetahui $\mathrm{pH}$ sebelum pencampuran. Pengukuran $\mathrm{pH}$ menggunakan pH meter.

c. Homogenasi

Nira yang sudah diketahui kadar pHnya kemudian dicampur dengan kitosan menggunakan homogenizer dengan variasi $0 \%, 1 \%, 2 \%$ dan maltodeksrin $50 \%$ dan $100 \%$.

\section{d. Pengukuran $\mathrm{pH}$}

Nira yang sudah dicampur diukur kembali kadar pHnya untuk mengetahui perbandingan $\mathrm{pH}$ sebelum dicampur dengan $\mathrm{pH}$ sesudah dicampur.

\section{e. Persiapan Pemanasan}

Bahan yang sudah dicampur dan diukur pH nya kemudian diletakkan pada loyang berbentuk persegi panjang dengan ukuran 25 $x 30 \mathrm{~cm}$ dengan membentuk lapisan setebal 2$3 \mathrm{~cm}$.

f. Pemanasan

Proses pemanasan bertujuan untuk membentuk kristal pada bahan dengan cara menguapkan air menggunakan panas. Pada penelitian ini kristalisasi dilakukan menggunakan cabinet dryer dengan suhu 60
${ }^{\circ} \mathrm{C}$ dengan waktu selama 2 jam per sampel yang diletakkan pada rak bagian bawah dari cabinet dryer.

g. Pengecilan Ukuran

Penumbukan dilakukan dengan menumbuk bahan yang sudah kering untuk menghasilkan produk dengan ukuran partikel yang lebih kecil.

h. Pengayakan

Pengayakan bertujuan untuk menghasilkan bahan dengan ukuran yang seragam. Pada penelitian ini bahan yang sudah ditumbuk diayak dengan ayakan stainless stee/ 20 mesh.

i. Analisis

Produk yang sudah jadi dilakukan analisis meliputi kadar air, kadar abu, aktivitas antioksidan, gula reduksi, total fenol, rendemen, analisis warna, morfologi partikel dan ukuran serta or- ganoleptik (rasa dan aroma), analisis kimia yang dilakukan dibandingkan dengan produk komersil.

\section{Rancangan Penelitian}

Rancangan yang digunakan pada penelitian ini adalah Rancangan Acak Lengkap (RAL) dengan dua faktor yaitu konsentrasi kitosan (C) dan maltodekstrin (M). Bahan yang sudah tersedia akan dilakukan kombinasi pada setiap perlakuan (C1M1, C1M2, C2M1, C2M2, C3M1, dan C3M2) dan diulang sebanyak 3 kali, sehingga diperoleh 18 unit percobaan. Data hasil pengamatan kimia dan organoleptik dianalisis dengan analisis keragaman (Analysis of Variance) pada taraf nyata $5 \%$ menggunakan software Co-Stat. Pada parameter yang berbeda nyata, dilakukan uji lanjut menggunakan metode Uji Beda Nyata Jujur (BNJ) untuk semua parameter pada taraf nyata 5\% (Hanafiah, 2002).

\section{HASIL DAN PEMBAHASAN}

\section{Parameter Kimia}

\section{Kadar Air}

Hasil analisis keragaman, menyatakan bahwa interaksi antara konsentrasi khitosan (C) dan maltodekstrin (M) memberikan pengaruh nyata terhadap kadar air gula semut aren. Adapun grafik pengaruh kitosan dan maltodekstrin terhadap kadar air gula semut 
aren dapat dilihat pada Gambar 1.

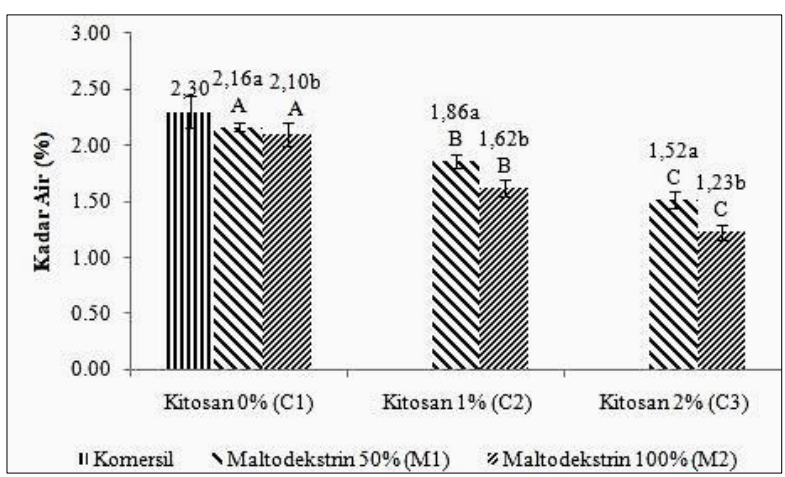

\section{Gambar 1. Pengaruh Kitosan dan Maltodekstrin Terhadap Kadar Air Gula Semut Aren.}

Keterangan: Huruf supercript yang berbeda menyatakan adanya perbedaan yang nyata $(p<0,05)$ dalam kelompok perlakuan.

Berdasarkan hasil yang diperoleh dari Gambar 1, kadar air yang dihasilkan oleh semua perlakuan kitosan dan maltodekstrin berkisar $1,23 \%-2,16 \%$. Semakin tinggi konsentrasi khitosan maupun maltodekstrin maka kadar air gula semut aren semakin rendah. Penurunan kadar air diduga disebabkan oleh peningkatan zat padat dalam gula semut aren. Menurut Krishnaiah dkk (2012), penambahan jumlah enkapsulan dapat meningkatkan zat padat terlarut dan mengurangi kandungan airnya. Dengan demikian, dapat menurunkan kadar air bubuk yang dihasilkan. Tharanathan dan Kittur (2003) menambahkan bahwa kemampuan dari kitosan yang tinggi untuk mengikat air menjurus ke viskositas yang tinggi bertanggung jawab terhadap kemampuan dalam menurunkan kadar air. Hal ini juga sejalan dengan pendapat Hui (2002) bahwa penambahan maltodekstrin dengan jumlah yang banyak dapat menurunkan kadar air suatu bahan.

Penambahan maltodekstrin juga meningkatkan total padatan dimana maltodekstrin dapat berfungsi sebagai bahan pengisi serta mampu menurunkan kadar air bahan (Oktaviana, 2012). Kemampuan mengikat air dari kedua bahan menyebabkan rendahnya kadar air yang terbentuk, hal ini disebabkan keterikatan air yang kuat sehingga kadar air yang teruapkan pada proses analisis yang terhitung sebagai kadar air memiliki konsentrasi yang rendah, ikatan yang terbentuk adalah ikatan hidrogen namun air dalam bentuk ini masih memiliki sifat air bebas dan dapat dikristalkan dalam proses pembekuan. Berdasarkan SNI 01-3743-1995 kadar air gula aren yang baik maksimal $3 \%$. Dari hasil yang diperoleh menunjukkan bahwa perlakuan kombinasi kitosan dan maltodekstrin yang dilakukan pada penelitian ini sudah memenuhi standar yang ditetapkan.

\section{Aktivitas Antioksidan}

Hasil analisis keragaman, menyatakan bahwa interaksi antara konsentrasi khitosan (C) dan maltodekstrin (M) memberikan pengaruh nyata terhadap aktivitas antioksidan gula semut aren. Adapun pengaruh kitosan dan maltodekstrin terhadap aktivitas antioksidan dapat dilihat pada Gambar 2.

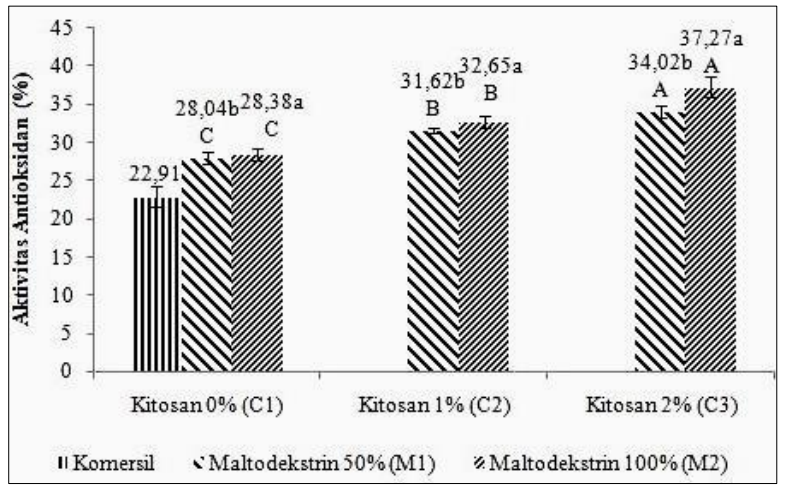

\section{Gambar 2. Pengaruh Kitosan dan Maltodekstrin Terhadap Aktivitas Antioksidan Gula Semut Aren.}

Keterangan: Huruf supercript yang berbeda menyatakan adanya perbedaan yang nyata $(p<0,05)$ dalam kelompok perlakuan.

Berdasarkan Gambar 2, aktivitas antioksidan yang dihasilkan pada gula semut aren berkisar 28,04\%-37,27\%. Aktivitas antioksidan gula semut aren semakin meningkat seiring dengan bertambahnya konsentrasi kedua perlakuan yakni kitosan dan maltodekstrin. Hal ini disebabkan semakin tinggi konsentrasi kitosan yang digunakan dapat meningkatkan aktivitas antioksidan dalam gula semut aren karena kitosan dapat digunakan sebagai antioksidan yang memiliki 
gugus amina yaitu $\mathrm{NH}_{2}$ yang dapat menangkal radikal bebas (Xie et al, 2001). Sehingga semakin banyak penambahan kitosan akan meningkatkan aktivitas antioksidan pada gula semut aren. Aprilia (2015) mengatakan kitosan merupakan turunan dari kitin melalui proses deasitelasi. Kitin adalah komponen penting dalam eksoskeleton hewan, terutama pada krustasea, moluska, dan insekta. Kitosan memliki banyak manfaat di berbagai bidang, diantaranya adalah biomedicine, produk farmasi, pengawetan makanan, dan reduksi bakteri. Pada bidang biomedicine, kitosan dapat berperan sebagai antioksidan.

Aktivitas antioksidan pada perlakuan maltodekstrin yang berbeda memberikan pengaruh yang berbeda nyata. Pada penelitian ini semakin tinggi konsentrasi maltodekstrin semakin tinggi pula aktivitas antioksidan yang terdapat dalam gula semut aren. Sesuai dengan pernyataan Ramadhia dkk., (2012), bahwa penggunaan maltodekstrin dapat melindungi terjadinya pelepasan komponen nutrisi, melindungi senyawa penting seperti komponen antioksidan akibat suhu ekstrim, karena maltodekstrin memiliki kemampuan membentuk body dan memiliki daya ikat yang kuat terhadap senyawa yang tersalut. Penambahan maltodekstrin sangat mempengaruhi peningkatan aktivitas antioksidan, dimana maltodekstrin dapat menjaga senyawa senyawa antioksidan, sehingga selama pemanasan meskipun terjadi kontak dengan panas namun tidak merusak aktivitas antioksidan secara keseluruhan.

\section{Gula Reduksi}

Hasil analisis keragaman, menyatakan bahwa interaksi antara konsentrasi khitosan (C) dan maltodekstrin (M) memberikan pengaruh nyata terhadap gula reduksi gula semut aren. Adapun pengaruh kitosan dan maltodekstrin terhadap gula reduksi gula semut aren dapat dilihat pada Gambar 3.

Gula reduksi yang dihasilkan oleh semua perlakuan dengan perlakuan kitosan dan maltodekstrin pada gula semut aren berkisar $6,57 \%$ sampai $8,63 \%$. Semakin meningkatnya konsentrasi kitosan yang ditambahkan maka semakin rendah kadar gula reduksi yang dihasilkan karena kemampuan kitosan dalam melindungi produk dari reaksi maillard yang menjadi salah satu indikasi terjadinya perubahan sukrosa menjadi glukosa dan fruktosa. Menurut Sardjono, dkk. (1985) kenaikan kadar gula reduksi terjadi sejalan dengan kenaikan kadar air selama penyimpanan dan proses fermentasi yang terjadi. Semakin rendah nilai gula reduksi maka semakin bagus kualitas gula tersebut.

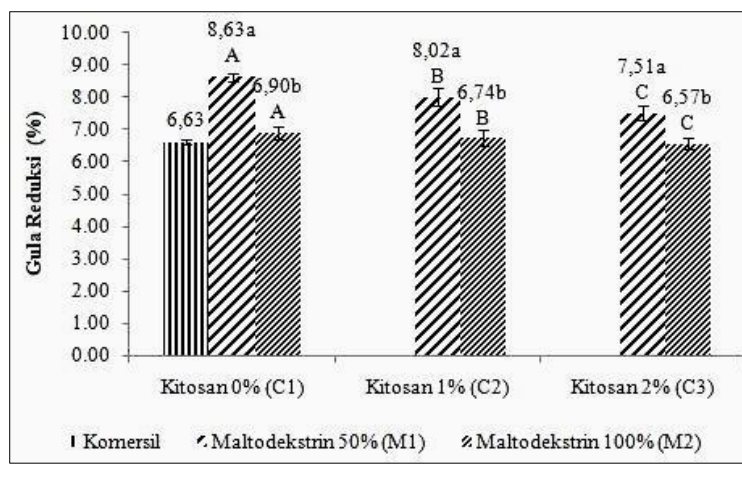

\section{Gambar 3. Pengaruh Kitosan dan Maltodekstrin Terhadap Gula Reduksi Gula Semut Aren.}

Keterangan: Huruf supercript yang berbeda menyatakan adanya perbedaan yang nyata $(p<0,05)$ dalam kelompok perlakuan.

Pada penelitian ini didapatkan semakin tinggi konsentrasi maltodekstrin maka semakin rendah gula reduksi yang dihasilkan. Berdasarkan penelitian Badmus dkk (2016) ditemukan kadar sukrosa yang sangat tinggi pada gula semut aren dan kadar glukosa, sukrosa, dan maltosa sangat rendah. Hal ini sejalan dengan penelitian Naknean dan Meenue bahwa karakteristik nira yang dipanaskan akan mengandung sukrosa $(59,15 \%)$, glukosa $(4,01 \%)$ dan fruktosa $(4,42 \%)$. Penelitian ini sesuai dengan SNI 013743-1995 kadar gula aren yang baik minimal $6 \%$. Dari hasil yang diperoleh menunjukkan bahwa perlakuan kombinasi kitosan dan maltodekstrin yang dilakukan pada penelitian ini sudah memenuhi standar yang ditetapkan.

\section{Total Fenol}

Hasil analisis keragaman, menyatakan bahwa interaksi antara konsentrasi khitosan (C) dan maltodekstrin (M) memberikan pengaruh nyata terhadap total fenol gula 
semut aren. Interaksi antara kitosan dan maltodekstrin terhadap total fenol gula semut aren dapat dilihat pada Gambar 4.

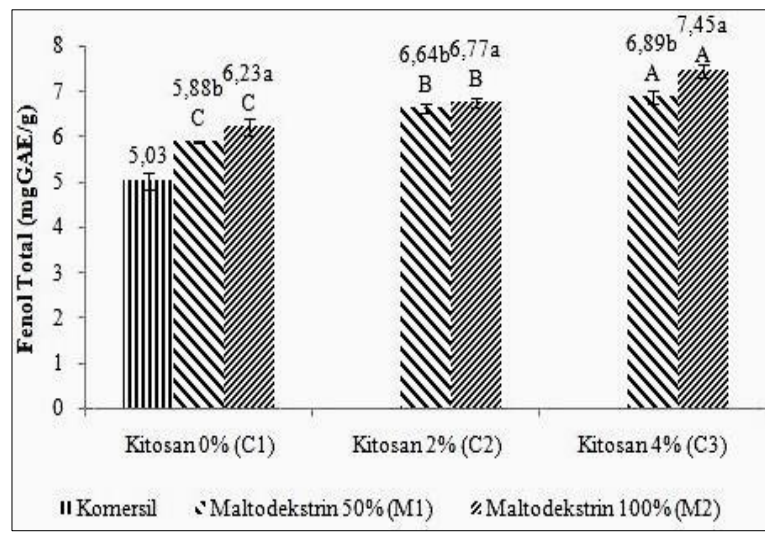

Gambar 4. Pengaruh Kitosan dan

Maltodekstrin Terhadap Total Fenol

Gula Semut Aren.

Keterangan: Huruf supercript yang berbeda menyatakan adanya perbedaan yang nyata $(p<0,05)$ dalam kelompok perlakuan.

Berdasarkan Gambar 4, total fenol yang dihasilkan oleh semua perlakuan pada gula semut aren berkisar 5,88\%- 7,45\%. Aktivitas antioksidan pada gula semut aren dimana fenol memiliki korelasi dimana semakin meningkatnya aktivitas antioksidan maka semakin tinggi pula total fenol dalam bahan, berdasarkan Rafi dkk (2012) mengatakan aktivitas antioksidan umumnya ditimbulkan oleh adanya senyawa fenolik baik dalam bentuk polifenol maupun asam fenolat di dalamnya. Turunan senyawa fenolik merupakan salah satu metabolit sekunder yang diproduksi oleh tumbuhan. Senyawa fenolik dapat memiliki aktivitas sebagai antioksidan, antitumor, antiviral dan antibiotik dan diantara senyawa fenol alami yang telah diketahui lebih dari seribu struktur, flavonoid merupakan golongan terbesar (Apak et al., 2007).

Perlakuan maltodekstrin berpengaruh terhadap semakin besarnya kemampuan dalam menangkap radikal bebas DPPH. Aktivitas antioksidan pada nira aren berhubungan erat dengan total fenol yang terkandung didalamnya yang berfungsi sebagai penangkal radikal bebas. Pada penelitian Badmus (2016) didapatkan total fenol yang terdapat pada gula semut aren yakni berkisar antara 5,82-5,83. Sesuai dengan pernyataan Ramadhia dkk., (2012), bahwa penggunaan maltodekstrin dapat melindungi terjadinya pelepasan komponen nutrisi, melindungi senyawa penting seperti komponen antioksidan akibat suhu ekstrim, karena maltodekstrin memiliki kemampuan membentuk body dan memiliki daya ikat yang kuat terhadap senyawa yang tersalut. Dari data diatas didapatkan bahwa penambahan kitosan dan maltodekstrin memberikan pengaruh terhadap meningkatnya total fenol dibandingkan dengan gula semut komersil yang tidak menggunakan penambahan apapun.

\section{Kadar Abu}

Hasil analisis keragaman, menyatakan bahwa interaksi antara konsentrasi khitosan (C) dan maltodekstrin (M) memberikan pengaruh nyata terhadap kadar abu gula semut aren. Interaksi antara kitosan dan maltodekstrin terhadap kadar abu gula semut aren dapat dilihat pada Gambar 5.

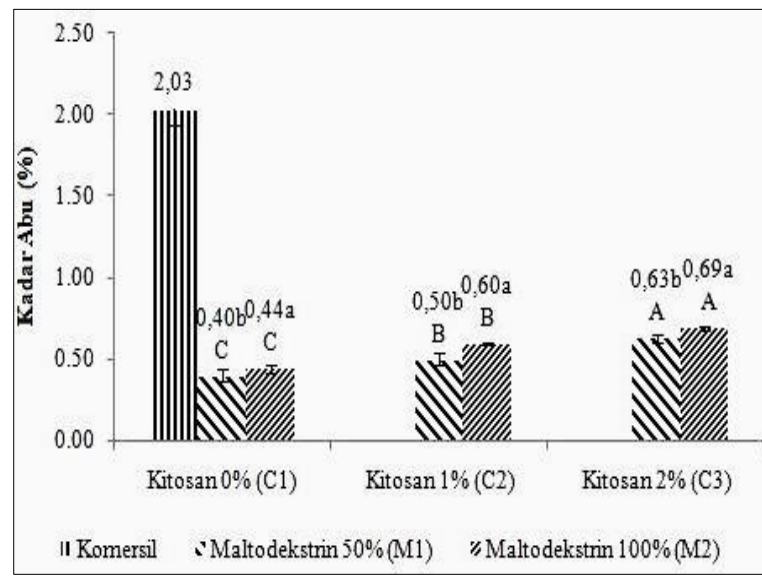

\section{Gambar 5. Pengaruh Kitosan dan Maltodekstrin Terhadap Kadar Abu Gula Semut Aren.}

Keterangan: Huruf supercript yang berbeda menyatakan adanya perbedaan yang nyata $(p<0,05)$ dalam kelompok perlakuan.

Berdasarkan Gambar 5, kadar abu yang dihasilkan dari semua perlakuan pada gula semut aren berkisar $0,40 \%$ sampai 0,69\%. Kadar abu tertinggi terdapat pada penambahan kitosan $2 \%$ (C3), peningkatan kadar abu dipengaruhi oleh keberadaan kadar 
mineral yang terdapat pada kitosan yang digunakan yakni sebesar $0,3 \%$. Pada dasarnya kitosan melalui proses demineralisasi untuk mengurangi kadar mineral yang terdapat pada kitosan ter sebut namun tidak dapat menghilangkan kandungan mineral pada kitosan secara keseluruhan. Proses demineralisasi bertujuan untuk menghilangkan garam-garam anorganik atau kandungan mineral yang ada pada kulit udang. Kandungan mineral utamanya adalah $\mathrm{CaCO}_{3}$ dan $\mathrm{Ca}_{3}\left(\mathrm{PO}_{4}\right)_{2}$ dalam jumlah kecil, mineral yang terkandung dalam kulit udang ini lebih mudah dipisahkan dibandingkan dengan protein karena hanya terikat secara fisik.

\section{Semakin tinggi konsentrasi} maltodekstrin yang ditambahkan maka kadar abu bahan bahan semakin meningkat. Hal ini disebabkan karena sifat maltodekstrin yang berperan sebagai filler yang mampu menjaga keberadaan unsur yang terkandung dalam bahan. Berdasarkan Hidayat (2002) yang menyatakan bahwa penggunaan maltodekstrin sebagai subtitusi glukosa menyebabkan tekanan osmotik produk menjadi lebih mudah, sehingga konsen- tasi padatan mineral dan nutrisinya akan meningkat.

\section{Rendemen}

Hasil analisis keragaman, menyatakan bahwa konsentrasi khitosan (C) dan maltodekstrin (M) memberikan pengaruh nyata terhadap rendemen gula semut aren. Pengaruh kitosan dan maltodekstrin terhadap nilai rendemen gula semut aren dapat dilihat pada Gambar 6.

Berdasarkan Gambar 6, rendemen yang dihasilkan oleh semua perlakuan pada gula semut aren berkisar 14,30\%-24,03\%. Rendemen gula semut aren pada perlakuan kitosan dan maltodekstrin mengalami peningkatan seiring dengan meningkatnya konsentrasi yang ditambahkan. Hal ini disebabkan penggunaan maltodekstrin pada produk berfungsi untuk memperbesar volume dan meningkatkan total padatan bahan, sehingga rendemen yang diperoleh semakin tinggi. Peningkatan rendemen dipengaruhi oleh banyaknya jumlah maltodektrin yang ditambahkan, karena semakin banyak maltodektrin akan semakin besar total padatan yang diperoleh. Total padatan pada bahan yang dikeringkan menyebabkan rendemen yang dihasilkan juga akan semakin tinggi (Yuliawaty dan Susanto, 2015).

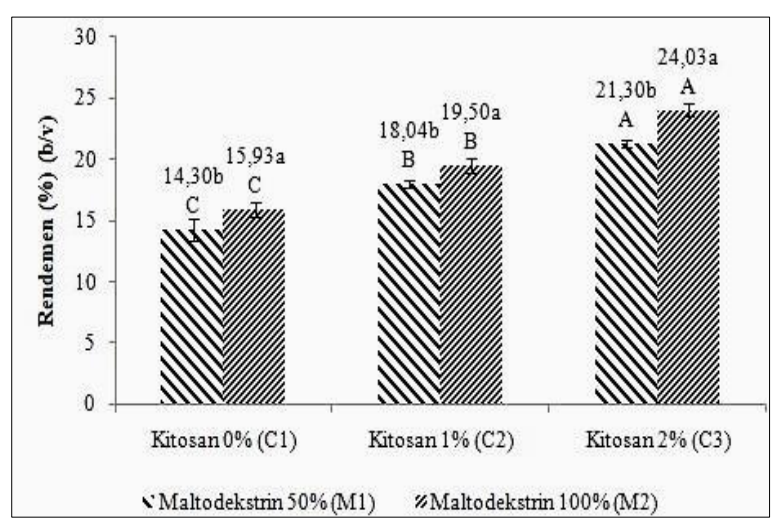

Gambar 6. Pengaruh Kitosan dan Maltodekstrin Terhadap Rendemen Gula Semut Aren.

Keterangan: Huruf supercript yang berbeda menyatakan adanya perbedaan yang nyata $(p<0,05)$ dalam kelompok perlakuan.

\section{Warna}

Hasil analisis keragaman, menyatakan bahwa interaksi antara konsentrasi khitosan (C) dan maltodekstrin (M) memberikan pengaruh nyata terhadap nilai ${ }^{\circ}$ Hue gula semut aren. Pengaruh kitosan dan maltodekstrin terhadap nilai ${ }^{\circ}$ Hue dapat dilihat pada Gambar 7.

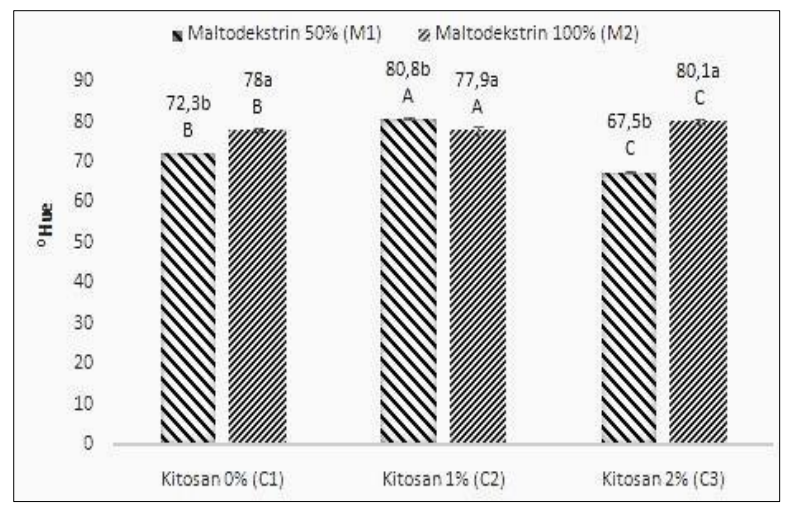

$\begin{array}{ccr}\text { Gambar 7. Pengaruh } & \text { Kitosan } & \text { dan } \\ \text { Maltodekstrin } & \text { Terhadap } & \text { Warna } \\ & \text { Gula Semut Aren. }\end{array}$

Keterangan: Huruf supercript yang berbeda menyatakan adanya perbedaan yang nyata $(p<0,05)$ dalam kelompok perlakuan. 
Berdasarkan Gambar 7, menunjukkan bahwa rerata warna nilai ${ }^{\circ}$ Hue yang dihasilkan oleh semua perlakuan pada gula semut aren berkisar 67,53 sampai 80,77 yang menunjukkan warna yellow red (cokelat). Terbentuknya warna coklat diduga disebabkan oleh interaksi asam amino bebas dalam khitosan dengan senyawa karbonil yang terkandung dalam gula semut. Hal ini didukung oleh pernyataan Lestari, et al. (2019), interaksi antara senyawa asam amino bebas yang terdapat dalam kitosan dengan senyawa karbonil yang terkandung di dalam gula pereduksi yaitu glukosa, galaktosa dan fruktosa dengan bantuan pemanasan.

Adapun pengaruh maltodekstrin pada warna gula semut aren yakni dengan penambahan maltodekstrin menyebabkan warna cenderung semakin putih dan sedikit kecoklatan (Soedibyo, 2002). Walaupun maltodekstrin memiliki sifat browning yang rendah namun paparan panas tetap dapat mengakibatkan perubahan warna menjadi cenderung sedikit kecoklatan tidak berubah menjadi coklat pekat. Oleh karena itu semakin tinggi maltodekstrin maka warna produk akan semakin jauh dari warna aslinya (Putra dan Ekawati, 2013).

\section{Ukuran Partikel}

Pengaruh kitosan dan maltodekstrin terhadap ukuran partikel dapat dilihat pada Gambar 8. Pada analisis ukuran partikel gula semut aren didapatkan rerata ukuran yakni berkisar antara 238,63 $\mu \mathrm{m}-531,73 \mu \mathrm{m}$. Ukuran partikel tertinggi yakni pada perlakuan kitosan 2\% (C3) dan maltodekstrin 50\% (M1), sedangkan ukuran partikel terendah yakni pada perlakuan kitosan $1 \%$ (C2) dan maltodekstrin $100 \%$ (M2). Hasil ini tidak sesuai dengan pernyataan Pakki dkk (2016) yakni bahwa ada keterkaitan antara konsentrasi kitosan yang digunakan dengan ukuran nanopartikel yang terbentuk. Semakin besar konsentrasi kitosan yang digunakan maka semakin besar pula ukuran partikel yang dihasilkan. Faktor lainnya yang mempengaruhi ukuran nanopartikel adalah $\mathrm{pH}$. Perbedaan $\mathrm{pH}$ berpengaruh pada jumlah ion amin yang akan terprotonasi. Hal ini sesuai denganpenelitian yang dilakukan oleh Hui dan Gao (2009) yang menunjukkan bahwa besar $\mathrm{pH}$ sangat mempengaruhi ukuran dari nanopartikel. Pada rentang $\mathrm{pH}$ 3,5-5,5 ukuran nano-partikel semakin kecil seiring dengan semakin tingginya nilai $\mathrm{pH}$. Begitu pun dengan maltodekstrin, Rizkila (2018) mengatakan bahwa semakin tinggi kon- sentrasi maltodekstrin yang digunakan maka semakin besar pula ukuran partikel bahan yang terbentuk.

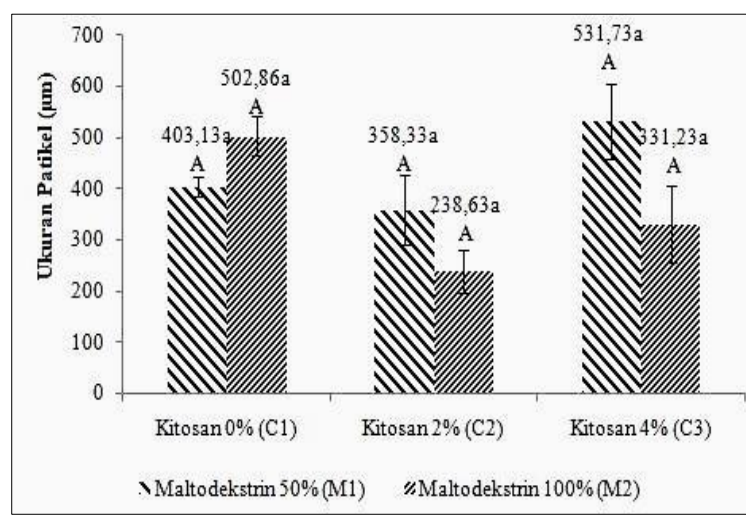

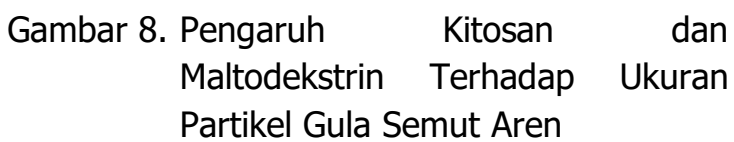

Keterangan: Huruf supercript yang berbeda menyatakan adanya perbedaan yang nyata $(p<0,05)$ dalam kelompok perlakuan.

\section{Morfologi Partikel}

Adapun data yang dianalisis yakni tentang ukuran partikel yang diukur dengan menghitung diameter partikel, sedangkan bentuk partikel memberikan gambaran tentang luas permukaan spesifik partikel dan teksturnya (kasar atau halus permukaan partikel) (Handayani, 2011). Adapun hasil analisis yang dilakukan dapat dilihat pada Gambar 9-14.

Pada Gambar 9-14 dapat dilihat seiring dengan penambahan kitosan permukaan partikel gula semut aren cenderung lebih halus. Adapun pengaruh homogenisasi pada morfologi partikel gula semut aren yakni lamanya waktu homogenisasi dengan menggunakan homogenizer ultra turax dengan intensitas 6000 - $11.000 \mathrm{rpm}$ memiliki ukuran partikel 
yang tidak berbeda signifikan. Kecepatan homogenisasi yang digunakan pada gula semut aren diduga tidak memberikan pengaruh yang signifikan terhadap perbedaan

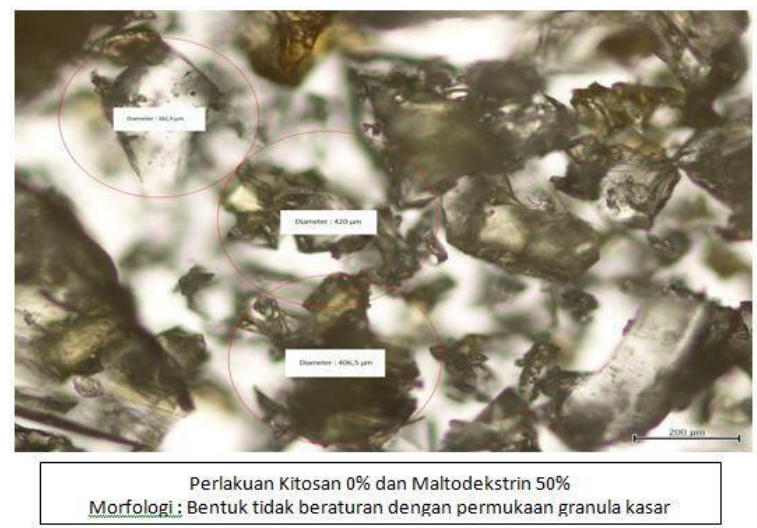

Gambar 9. C1M1

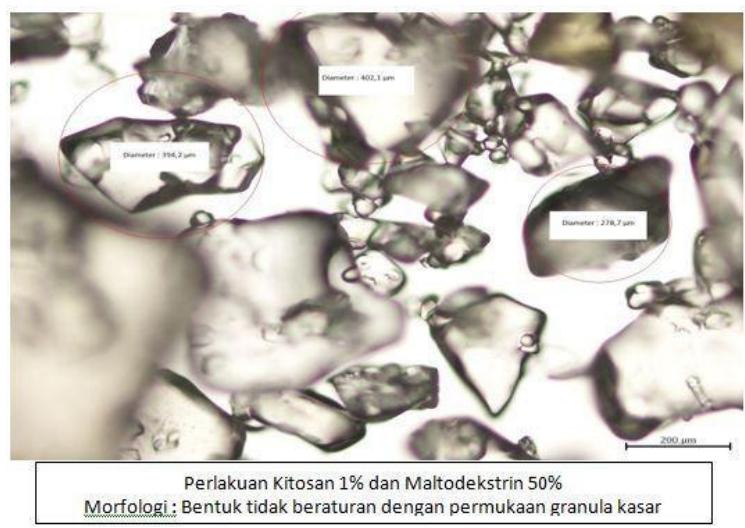

Gambar 11. C2M1

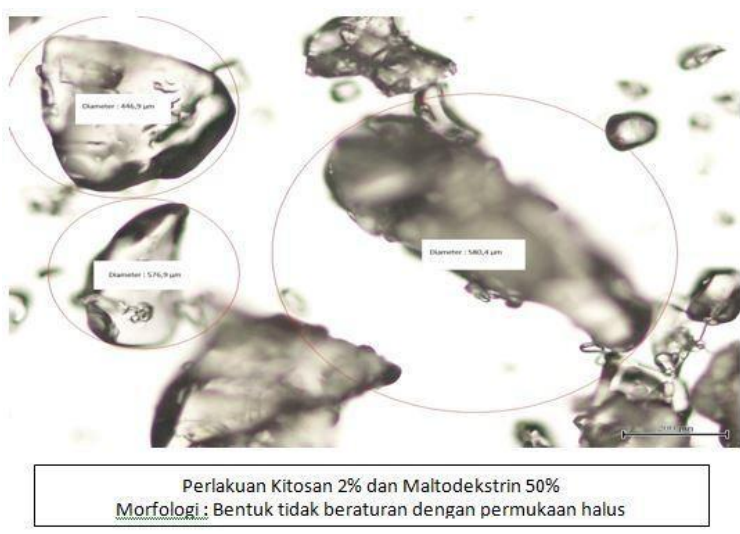

Gambar 13.C3M1 ukuran partikel karena perbedaan kecepatan yang tidak terlalu besar dan perlakuan homogenisasi dilakukan dengan waktu yang sama.

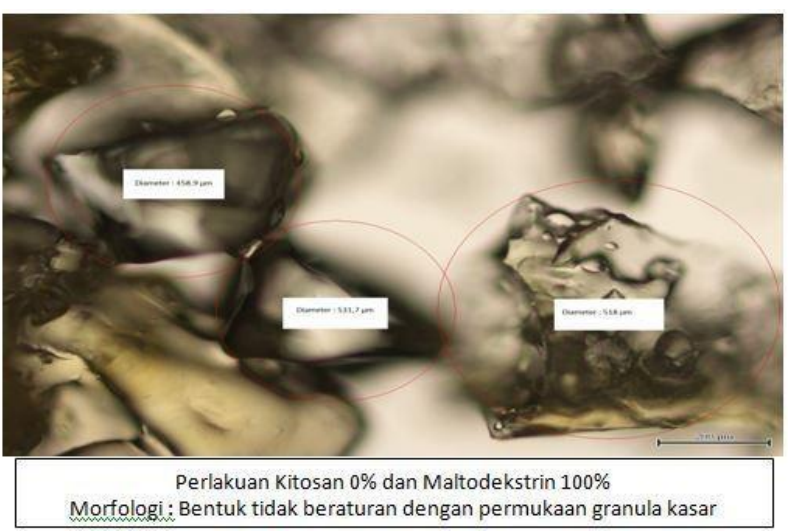

Gambar 10. C1M2

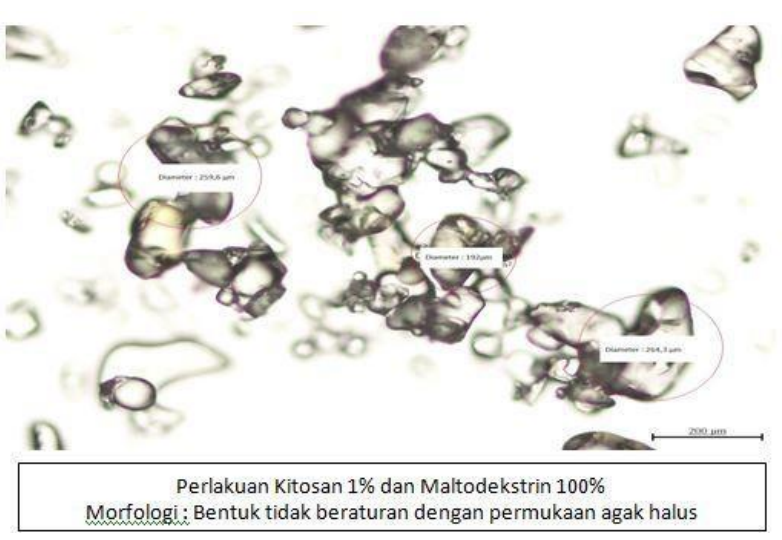

Gambar 12. C2M2

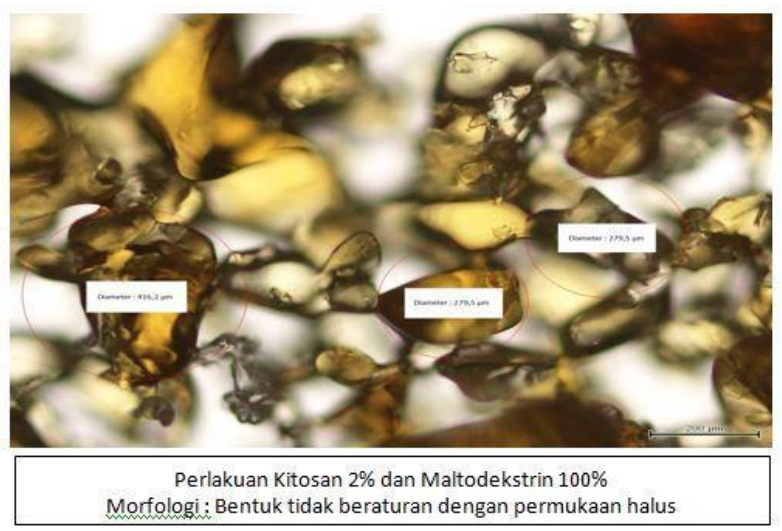

Gambar 14. C3M2 


\section{Aroma}

Berdasarkan penelitian yang telah dilakukan, bahwa interaksi kitosan dan maltodekstrin memberikan pengaruh yang tidak berbeda nyata terhadap aroma gula semut aren. Pada penilaian karakteristik aroma gula aren semut dengan uji hedonik, panelis memberikan penilaian tidak suka, agak suka, netral, suka dan sangat suka. Tingkat kesukaan panelis terhadap aroma gula semut aren yang dihasilkan pada semua perlakuan yaitu suka.

\section{Rasa}

Perlakuan konsentrasi khitosan dan maltodekstrin memberikan pengaruh yang tidak berbeda nyata terhadap organoleptik rasa pada gula semut aren. Hal ini disebabkan karena kedua bahan yang digunakan (khitosan dan maltodekstrin) bersifat netral atau memiliki rasa hambar. Pengaruh yang diberikan oleh kedua bahan tambahan hanya terlibat pada proses perlindungan produk pada pemanasan saat dilakukan proses enkapsulasi. Hasil penilaian panelis terhadap rasa gula semut aren yakni rasa gula semut aren kuat.

\section{KESIMPULAN}

Berdasarkan kajian yang telah dilakukan, maka dapat disimpulkan sebagai berikut:

1. Interaksi antara penambahan kitosan dan maltodekstrin memberikan pengaruh yang berbeda nyata terhadap kadar air, aktivitas antioksidan, gula reduksi, fenol total, ukuran partikel, dan warna. Namun tidak berpengaruh nyata terhadap kadar abu, rendemen dan organoleptik (rasa dan aroma).

2. Penambahan kitosan dan maltodekstrin memberikan pengaruh yang berbeda nyata terhadap kadar air, aktivitas antioksidan, gula reduksi, fenol total, kadar abu, warna, rendemen, dan ukuran partikel namun tidak berpengaruh nyata terhadap organoleptik (rasa dan aroma).

3. Penambahan kitosan dan maltodekstrin menurunkan kadar air gula semut aren, namun meningkatkan aktivitas antioksidan, gula reduksi, fenol, kadar abu, dan rendemen. Sedangkan pada uji warna, ukuran partikel, dan organoleptik didapatkan hasil yang fluktuatif.

4. Perlakuan terbaik yang didapatkan adalah perlakuan kitosan $2 \% \quad$ (C3) dan maltodekstrin $100 \%$ (M2) dengan kadar air 1,23\%; aktivitas antioksidan 37,26\%; gula reduksi $6,57 \%$; fenol total $7,45 \%$; kadar abu $0,69 \%$; rendemen $24,02 \%$; oHue 80,04; ukuran partikel $331,23 \mu \mathrm{m}$ dengan morfologi permukaan halus bentuk tidak beraturan; organoleptik aroma agak suka dan aroma khas gula semut agak lemah; organoleptik rasa suka dan manis.

\section{DAFTAR PUSTAKA}

Anonim. 2010. Laporan Tahunan Dinas Perkebunan. Provinsi Sulawesi Utara.

Apak, R., Güçlü, K., Demirata, B., Özyürek, M., Çelik, S. E., Bektaşoğlu, B., Berker K.I., \&Özyurt, D. (2007). Comparative Evaluation of Various Total Antioxidant Capacity Assay Applied to Phenolic Compounds with The CUPRAC Assay. Molecules, 12, 1496-1547.

Aprilia, D. 2015. Potensi Kitosan Seagai Agen Antioksidatif pada Hepar yang Diinduksi Plumbum. Majority 4(8): 12-22.

Badan Standarisasi Nasional. 1995. Standar Nasional Indonesia (SNI) Gula Palma 01-3743-1995. Dewan Standarisasi Nasional. Jakarta.

Badmus, A.A., Y.A. Yusof., N.L. Chin dan N.A. Aziz. 2016. Antioxidant Ca- pacity and Phenolic of Spray Dried Arenga pinnata Juice Powder. Journal of Agriculture Science and Technology B. 3(6): 209213.

Bansode, S.S., Banarjee, S.K., Gaikwad, S.L., Jadhav, R., and Thorat, R.M., 2010. Microencapsulation: A Review. International Journal of Pharmaceutical Sciences Review and Research 1, 38-43.

Ferita, L., Tawarati., dan Syarif. Z. 2015. Identifikasi dan karakterisasi tanaman enau (Arenga pinnata) di Kabupaten Gayo Lues. Prosid- ing Seminar Nasional 
Masyarakat Biodiversitas Indonesia. ISSN: 2401-8050. 31-37.

Handayani, P., 2011, Optimasi komposisi Cetyl Alcohol Sebagai Emulsifying Agent Gliserin Sebagai Humec- tant Dalam krim Sunscreen Ekstrak Kental Apel Merah (Pyrus malus L.) Aplikasi Desain Faktori- al. Skripsi, Fakultas Farmasi, Uni- versitas Sanata Dharma, Yogyakarta.

Hidayat, B. 2002. Optimasi Proses Produksi dan Karakterisasi Maltodekstrin (DP3-9) dari Pati Gandum. Tesis. Program Pascasarjana. IPB, Bogor.

Hui, L dan Gao C. 2009. Preparation and properties of ionically cross-linked chitosan nanoparticles. Polymers for Advance Technologies. 20 (7): 613-619.

Hui, Y. 2002. Encylopedia of Food Science and Technology Handbook. IVCH Publisher, Inc. New York.

Joseph, G. H., Layuk, P. 2012. Pengolahan Gula Semut Dari Aren. B Palma, 13(1): 60-65.

Kaho, A.R. 2006. Kitin Dan Kitosan Dari Limbah Cacing. Suara Merdeka, Ragam.

Krishnaiah, D., Sarbatly, R., dan Nithyanandam. 2012. Microencapsulation of Morinda citrifolia L. extract by spray-drying. Chemical Engineering Research and Design 90 :622-632.

Lestari, S.D., Baehaki, A., Meliza, R. 2019. Aktivitas antibakteri kompleks kitosanmonosakarida terhadap patogen dalam surimi ikan gabus sebagai model matriks pangan. Jurnal Pengolahan Hasil Perikanan Indonesia. 22(1): 80-88.

Mashud, N., A. Lay, E.T. Tenda, R.B. Maliangkay, dan Torar, D.J. 2011. Budidaya dan Pascapanen Aren. Balai Penelitian Tanaman Palma. Manado.

Mishra, M., 2016. Handbook of Encapsulation and Controlled Release. CRC Press Taylor \& Francis Group. 1-15.

Muchtadi, D. 2010. Kedelai: Komponen Bioaktif Untuk Kesehatan. Bandung: Alfabeta.

Mustaufik, Dwiyanti, H. 2007. Rekayasa Pembuatan Gula Aren Kristal yang diperkaya dengan Vitamin A dan Uji Preferensinya kepada Konsumen. Laporan Penelitian Dosen Muda. Jurusan Teknologi Pertanian. Universitas Jenderal Soedirman. Purwokerto.

Oktaviana, D. 2012. Kombinasi Maltodekstrin dan Suhu Pema- nasan Terhadap Kualitas Minuman Serbuk Instan Belimbing Wuluh (Avverhoa bilimbi Linn). Skripsi. UAJY. Yogyakarta.

Pakki, E., Sumarheni., F. Aisyah., Ismail, S. Safirahidzni. 2016. Formulasi Nanopartikel Ekstrak Bawang Dayak (Eleutherine americana (Aubl) Merr) Dengan Variasi Konsentrasi Kitosantripolifosfat (TPP). J. Trop. Pharm. Chem 3(4): 251-263.

Pitopang, R., Khaeruddin, I., Tjoa, A., dan Burhanuddin, I.F. 2008. Pengenalan Jenis-Jenis Pohon yang Umum di Sulawesi. Panduan Lapangan. Universitas Tadulako, Sulawesi Tengah.

Putra, S.D.R dan Ekawati L.M. 2013. Kualitas Minuman Serbuk Instan Kulit Buah Manggis dengan Varia- si Maltodekstrin dan Suhu Pemanasan. Universitas Atma Jaya. Yogyakarta.

Rafi, M., Widyastuti, N., Suradikusumah, E danL. Darusman, L.T. 2012.Aktivitas Antioksidan, Kadar Fenol dan Flavonoid Total dari Enam Tumbuhan Obat Indonesia. Jurnal Bahan Alam Indonesia ISSN 1412-2855. 8(3): 67-70.

Ramadhia, M., Kumalaningsih, $\mathrm{S}$ dan Santoso, I. 2012. Pembuatan Tepung Lidah Buaya (Aloe vera L.) dengan Metode Foam-Mat Drying. Jurnal Teknologi Pertanian. 13(2): 125-137.

Rizkila, V. 2018. Pengaruh Konsentrasi Maltodekstrin dan Kecepatan Homogenisasi Terhadap Karekteristik Serbuk Ekstrak Daun Cincau Hitam (Mesona Palustris BI). Skripsi. Universitas Mataram. Mataram.

Saloko, S., Darmadji, P, Setiaji, B., dan Pranoto, Y. 2012. Structural analysis of spray-dried coconut shell liquid smoke powder. Jurnal Teknologi dan Industri Pangan. 23(2):173-179.

Sardjono, E.A. Basrah, dan O. Sukardi. 1985. Penelitian dan Pengembangan Diversifikasi Produk dan Pengepakan 
Gula Merah Cetak. Bogor.

Soedibyo, M. 2002. Alat Simulasi Buah-buahan Segar dengan Mobil dan Kereta Api. Jurnal Hortikultura 2(1): 6-73.

Srihari, E., Lingganingrum, S., Farid dan Hervita S. 2010. Pengaruh Penambahan Maltodekstrin pada Pembuatan Santan Kelapa Bubuk. Jurnal Pangan, 3(4): 112-115.

Tharanathan, R.N. and Kittur, F.S, 2003. The Undisputed Biomolecule of Great Potential. Crit. Rev. Food Sei. Nurt; 43(2):145-171.

Timotius, K. H. 1982. Mikrobiologi Dasar. Universitas Kristen satya Wacana. Salatiga.

Xie W, P Xu, Q Liu. 2001. Antioxidant activity of water-soluble chitosan derivatives. Bioorg Med Chem Lett 11: 1699-1701.

Yuliawaty, S.T dan Susanto, W.H. 2015. Pengaruh Lama Pengeringan dan Konsentrasi Maltodekstrin Terhadap Karakteristik Fisik Kimia dan Organoleptik Minuman Instan Daun Mengkudu (Morinda citrifolia L). Jurnal Pangan dan Agroindustri 3(1):41-52. 